\title{
Androgenic response of Brazilian wheat genotypes to different pretreatments of spikes and to a gelling agent
}

\author{
Liane Balvedi Poersch-Bortolon ${ }^{(1)}$, Sandra Maria Mansur Scagliusi(2), \\ Elene Yamazaki-Lau ${ }^{(2)}$ and Maria Helena Bodanese-Zanettini ${ }^{(1)}$
}

\begin{abstract}
(1)Universidade Federal do Rio Grande do Sul, Departamento de Genética, Avenida Bento Gonçalves, no 9.500, Caixa Postal 15.053, CEP 91501-970 Porto Alegre, RS, Brazil. E-mail: lianebpoersch@yahoo.com.br, maria.zanettini@ufrgs.br (2)Embrapa Trigo, Rodovia BR-285, Km 294, Caixa Postal 3081, CEP 99050-970 Passo Fundo, RS, Brazil. E-mail: sandra.scagliusi@embrapa.br, elene.yamazaki-lau@embrapa.br
\end{abstract}

\begin{abstract}
The objective of this work was to analyze the androgenic response of Brazilian wheat genotypes to different pretreatments of the spikes, prior to the culture of isolated microspores, and to the effect of a gelling agent in the induction culture medium. Five genotypes were evaluated for embryo formation, green plant regeneration, and spontaneous chromosome duplication. Wheat spikes were subjected to two pretreatments: cold, at $4{ }^{\circ} \mathrm{C}$ for 21 days; and 2-hydroxynicotinic acid, at $32^{\circ} \mathrm{C}$ for two days. Culture media were evaluated with or without Ficoll as a gelling agent. Cold produced more embryos and green plants than the chemical pretreatment in four out of five genotypes. Only two genotypes treated with 2-hydroxynicotinic acid were able to produce plants, and one of them produced a single albino plant. Medium containing Ficoll produced more embryos than liquid medium and promoted a higher number of plants. Spontaneous chromosome duplication varies between genotypes and pretreatments, and shows high variability.
\end{abstract}

Index terms: Triticum aestivum, albinism, androgenesis, doubled haploid, isolated microspore culture, recalcitrance.

\section{Resposta androgênica de genótipos brasileiros de trigo a diferentes pré-tratamentos das espigas e a um agente gelificante}

Resumo - O objetivo deste trabalho foi analisar a resposta androgênica de genótipos brasileiros de trigo a diferentes pré-tratamentos das espigas, antes da cultura de micrósporos isolados, e ao efeito de um agente gelificante no meio de cultura de indução. Cinco genótipos foram avaliados quanto à formação de embriões, regeneração de plantas verdes e à duplicação espontânea dos cromossomos. Espigas de trigo foram submetidas a dois pré-tratamentos: frio, a $4^{\circ} \mathrm{C}$ por 21 dias; e ácido 2-hidroxinicotínico, a $32^{\circ} \mathrm{C}$ por dois dias. Os meios de cultura foram avaliados com ou sem Ficoll como agente gelificante. $\mathrm{O}$ frio produziu mais embriões e plantas verdes do que o pré-tratamento químico, em quatro dos cinco genótipos testados. Apenas dois genótipos tratados com ácido 2-hidroxinicotínico foram capazes de produzir plantas, e um deles produziu uma única planta albina. O meio com Ficoll produziu mais embriões do que o meio líquido e gerou maior número de plantas. A duplicação espontânea dos cromossomos varia entre os genótipos e os pré-tratamentos e apresenta alta variabilidade.

Termos para indexação: Triticum aestivum, albinismo, androgênese, duplo-haploide, cultura de micrósporos isolados, recalcitrância.

\section{Introduction}

The significance of haploid $(\mathrm{H})$ plants for plant breeding and genetic research was first recognized in 1921, when Bergner observed this natural phenomenon in Datura stramonium (Blakeslee et al., 1922). Four decades later, Guha \& Maheshwari (1964) observed that these plants could arise from immature pollen in vitro as an immediate product of meiosis, representing all the diversity of the parental post-meiotic haploid chromosome set. Haploid plants have normal development cycle; however, one notable exception is related to their reproductive structure because most haploid plants have defective anthers and are sterile. In the absence of homologous pairing, meiosis produces gametes with fewer than the necessary complement of chromosomes. The duplication of chromosomes - spontaneous or induced - overcomes this impasse to yield doubled haploid (DH) and fertile plants. In other words, it can produce completely homozygous plants, genetically normal, phenoty pically 
stable, and representing all gametophytic variation due to the recombination process of meiosis.

The fact that DH can yield completely homozygous plants in a single year is a valuable asset for breeding programs, since it can accelerate the development of new cultivars by up to five years, in comparison to conventional breeding. The use of DH plants can also increase the selection efficiency because fewer plants are necessary for the screening of selected traits, which reduces costs, allowing even in vitro selection of specific traits. Liu et al. (2002) used in vitro selection in studies of resistance to pathogens, mineral imbalances, and drought tolerance. Moreover, this tool is also used in basic and advanced research (Germanà, 2011), such as genetic analysis, induction of mutation, genome mapping, gene transfer (Abdollahi et al., 2007), and QTL detection (Seymour et al., 2012).

Although haploidization has been successfully achieved by different approaches (intergeneric hybridization, anther and microspore cultures), in a number of species, some important advantages are associated with isolated microspore culture (IMC), such as: abundance of microspores per spike, absence of anther walls that could damage the culture process, assurance that all developed embryos are microsporederived, better nutrient availability to cells in culture medium, and the possibility for easily tracking the development of individual cells (Liu et al., 2002). IMC protocols have been improved for many plant species; however, cereal microspore culture requires some adjustment to be used in large-scale, especially the rate of embryo induction, green plant regeneration, and spontaneous chromosome doubling (Castillo et al., 2009).

Androgenesis is one of the most remarkable examples of cellular totipotency. However, some conditions should be met for gametes to develop into a new plant. Stress pretreatments are considered crucial for triggering totipotency and activating the sporophytic pathway of the microspore cell (Shariatpanahi et al., 2006). The physiological conditions of donor plants and the microspore development stage are also very important because they can modify the androgenic response even in responsive genotypes (Germanà, 2011).

The objective of this work was to analyze the androgenic response of Brazilian wheat genotypes to different pretreatments of the spikes, prior to the culture of isolated microspores, and to the effect of a gelling agent in the induction culture medium.

\section{Materials and Methods}

The experiment was carried out at Embrapa Trigo, in Passo Fundo, Rio Grande do Sul, Brazil, in 2011/2012. Six genotypes were used to test androgenesis: five Brazilian wheat genotypes with unknown androgenic responses - 'MGS 1 Aliança', 'MGS Brilhante', 'BR 18 Terena', PF020037, and PF020062 -, and the responsive genotype 'Pavon 76' which was used as a control.

Seeds of donor plants were treated with an insecticide and a fungicide solution - 1:1 Gaucho (Imidacloprid $600 \mathrm{~g} \mathrm{~L}^{-1}$ ) : Baytan (Triadimenol $150 \mathrm{~g} \mathrm{~L}^{-1}$ ). Treated seed were distributed on a moistened germitest paper with distilled water, and kept in the dark, at $4^{\circ} \mathrm{C}$, for four days. After this period, seeds were transferred to a chamber $\left(24^{\circ} \mathrm{C}, 16\right.$ hours light) for approximately one week. The germinated seeds were transferred to $6.5 \mathrm{~kg}$ pots containing a mix of soil, vermiculite, and substrate (1:1:1), and moved to a Conviron growth chamber $\left(20^{\circ} \mathrm{C} / 15^{\circ} \mathrm{C}, 16\right.$ hours light $)$. Each pot received two germinated seeds. Twenty plants were grown per genotype. Half-strength Hoagland nutrient solution was applied once a week (100 mL per pot) until the end of tillering.

Tillers containing spikes were sampled when microspores were in the early to mid-uninucleated stage (confirmed by acetocarmine staining), and their stems were immediately placed in a flask containing distilled water. Tillers were wrapped in aluminum foil and stored in flasks with distilled water.

Two pretreatments were applied to the spikes before microspore extraction: cold, tillers were kept in distilled water and stored at $4{ }^{\circ} \mathrm{C}$ for $21 \pm 3$ days; and chemical, tillers were transferred to $50 \mathrm{~mL}$ of $100 \mathrm{mg} \mathrm{L}^{-1}$ 2-hydroxynicotinic acid (2-HNA) solution, and kept at $32^{\circ} \mathrm{C}$ for two days.

After pretreatments and prior to extraction, awns were removed with scissors, and the surface of donor spikes were sterilized for $15 \mathrm{~min}$ in $15 \%$ bleach $(0.038 \%$ active chlorine) solution, containing one drop of Tween 20 to eliminate external bacterial or fungal contaminants. Following disinfection, spikes were rinsed five times with sterile, distilled water. The outer glumes of each spikelet were discarded, and the flowers were removed from the rachis and transferred to a sterile miniblender cup (Waring, Thomas Scientific, Model 3392, Swedesboro, NJ, USA) containing $50 \mathrm{~mL}$ of refrigerated NPB-99 extraction medium (Liu et al., 
2002). Nine to 12 spikes were used for each extraction. The total number of spikes is described in Table 1.

Flowers were blended twice at low speed for 7-8 s, and the solution was transferred to a cold beaker. The solution was filtered through a $100 \mu \mathrm{m}$ sterile membrane into two $50 \mathrm{~mL}$ sterile centrifuge tubes, then it was centrifuged for five min at $100 \mathrm{~g}\left(4^{\circ} \mathrm{C}\right)$ using a swinging bucket rotor. Supernatant was discarded, and the pellets were resuspended in $35 \mathrm{~mL}$ of NPB-99 and centrifuged again. Two more cycles of centrifugation were repeated at the same speed. The final pellets were resuspended in $300-1,000 \mu \mathrm{L}$ NPB99, and the microspore concentration was verified using a hemocytometer. Cells were adjusted to a final concentration of approximately 80,000 cells $\mathrm{mL}^{-1}$.

Microspore suspension $(250 \mu \mathrm{L})$ was plated on $40 \times 11$ $\mathrm{mm}$ diameter Corning plastic Petri dishes containing $2,750 \mu \mathrm{L}$ NPB-99 and $0.001 \%$ arabic gum from the acacia tree, with or without $10 \%$ Ficoll PM400 as a gelling agent: half of each extraction was plated on medium with Ficoll, and the other half, in a medium without Ficoll. One immature ovary per milliliter was added to each plate; ovary donor spikes were sterilized under the same conditions as those of the microspore donor spikes. The plates were sealed with Parafilm and placed into a $150 \mathrm{~mm}$ Petri dish containing an open 35 $\mathrm{mm}$ Petri dish with sterile distilled water.

The Petri dishes were placed in the dark inside an incubator at $27^{\circ} \mathrm{C}$ for approximately 3-4 weeks. Embryos with at least $2 \mathrm{~mm}$ in size were transferred to $90 \times 15 \mathrm{~mm}$ Petri dishes containing $20 \mathrm{~mL}$ of GEM medium (Eudes et al., 2003). The Petri dishes were stored in a growth room and exposed to 16 hours of light per day, at $24^{\circ} \mathrm{C}$.

Once embryos had regenerated into green plants with roots and leaves, each plantlet was transferred to $14 \mathrm{~mL}$ rooting medium (Eudes et al., 2003) and maintained in the same room. When plantlet roots were well developed, they were transplanted into $500 \mathrm{~mL}$ PVC cups containing vermiculite (weekly fertilized) and covered with a beaker. After acclimation, plants were ready to be transplanted in the soil (two plants per $6.5 \mathrm{~kg}$ pot). They were grown in a controlled environment room, under the same conditions as those of the donor plants, until the end of the cycle. Colchicine treatment was not applied to plants, and chromosome doubling was verified by checking fertile spikes.

\section{Results and Discussion}

Visible differences in the total number of cells (cell yield) and stage of microspore development were observed between the two pretreatments. The number of uninucleated cells per spike was markedly higher in plants pretreated with cold, varying among genotypes from 41,672 to 107,410 cells, in comparison to 2,982 to 33,527 cells using 2-HNA (Table 1). The application of 2-HNA to tillers accelerated the development cycles of both spikes and cells, and the remaining leaves of tillers rapidly yellowed. The optical microscopy images indicated that most of the microspore cells were at the early binucleated stage after 2-HNA pretreatment, and some of these cells were identified as pollen grains.

In general, most of microspore cells continue along their normal gametophytic pathway, even after stress pretreatment. Only a small percentage of competent cells will follow the sporophytic pathway. Therefore, increasing the number of purified uninucleated cells per spike (yield) would likely increase the number of competent cells that would follow a sporophytic pathway. The cold pretreatment applied to the spikes generated better results (higher yield of cells), which increased the number of embryos and regenerated plants in four out of five tested Brazilian genotypes. On the other hand, the application of 2-HNA yielded lower

Table 1. Yield of microspore cells obtained from six wheat genotypes in response to different types of pretreatment.

\begin{tabular}{|c|c|c|c|c|c|c|}
\hline \multirow[t]{2}{*}{ Genotype } & \multicolumn{3}{|c|}{ 2-HNA } & \multicolumn{3}{|c|}{ Cold } \\
\hline & Number of spikes & Number of cells & Number of cells/spike & Number of spikes & Number of cells & Number of cells/spike \\
\hline 'Pavon 76' & 20 & 373,998 & 18,700 & 31 & $2,561,184$ & 82,619 \\
\hline PF020037 & 54 & $1,810,443$ & 33,527 & 42 & $3,037,956$ & 72,332 \\
\hline 'MGS 1 Aliança' & 32 & 312,198 & 9,756 & 29 & $2,209,734$ & 76,198 \\
\hline 'MGS Brilhante' & 23 & 193,332 & 8,406 & 30 & $3,222,315$ & 107,410 \\
\hline 'BR 18 Terena' & 40 & 119,265 & 2,982 & 42 & $1,750,243$ & 41,672 \\
\hline PF020062 & 56 & $1,120,194$ & 20,003 & 30 & $2,551,092$ & 85,036 \\
\hline
\end{tabular}


number of cells and embryos, and plants were obtained only from two Brazilian genotypes (PF020037 and 'MGS 1 Aliança'), and from 'Pavon 76' (responsive control).

Regarding embryo and plant development, cold treatment also triggered microspore embryogenesis more effectively than heat associated with 2-HNA. Shirdelmoghanloo et al. (2009) found similar results. These authors compared heat associated with chemical treatment (2-HNA) and cold, alone or combined with mannitol. In their study, a short period of cold (seven days at $4^{\circ} \mathrm{C}$ ) combined with mannitol promoted higher number of embryos and green plants. However, Konzak et al. (2000) reported opposite results regarding the benefits of 2-HNA as a chemical pretreatment for triggering embryogenesis. They observed that 2-HNA significantly increased the androgenic response in wheat microspore culture.

The application of high temperatures to spikes has been suggested to accelerate the rate at which 2-HNA triggers androgenesis in microspores (Liu et al., 2002). In the present study, 2-HNA was used as a pretreatment to verify these effects. However, our results significantly differed from those reported by Konzak et al. (2000), and Liu et al. (2002). Green plants were obtained from only one Brazilian genotype (PF020037), and it was a single albino plant from 'MGS 1 Aliança'.

In our study, wheat tillers were maintained in 2-HNA solution for two days at $32^{\circ} \mathrm{C}$, which resulted in yellowish leaves and accelerated spike development. One flower of the spike, removed after pretreatment and observed under an optical microscope, showed that the microspore cells were in a very advanced stage of development, and most were bicellular or pollen-like. None of the cells showed a "star-like" morphology, a feature generally associated with the onset of androgenesis (Maraschin et al., 2005). Considering the severe effect of the stress treatment with 2-HNA, less aggressive treatments to trigger microspore embryogenesis would be preferable. Collecting tillers during an earlier stage of microspore development, and reducing the time or the temperature of this type of pretreatment may also be useful for triggering the response in recalcitrant wheat genotypes.

Although widely used, the mechanism by which low temperatures elicit an androgenic response remains unclear. Cold has been shown to repress the gametophytic pathway by inducing symmetrical microspore mitotic divisions and delaying pollen development (Shirdelmoghanloo et al., 2009). Cold shock is also thought to ensure the survival of a greater number of cells (Shariatpanahi et al., 2006). According to these authors, the understanding of an accurate mechanism of stress, with respect to microspore embryogenesis, is far to be elucidated, regardless of the chosen stress type (cold, heat, chemical or others). Based on these information, some authors believe that cold is not a stress "per se", but an anti-stress that is actually protecting microspores more than harming them, and that the real stress is caused by starvation (Zoriniants et al., 2005).

Because of its importance for plant breeding and genetic studies, many protocols for producing $\mathrm{DH}$ plants via microspore embryogenesis have been reported for different crops and species. However, a positive response of the method is largely dependent on the genotype, and improvements are required for routine uses (Ferrie \& Caswell, 2011; Asif, 2013). Understanding the mechanisms involved in the microspore embryogenic process is important to identify a less genotype-dependent protocol.

Three important steps are primarily responsible for androgenic development: the acquisition of embryogenic capacity, the initiation of several cell divisions, and organ formation and differentiation (Maraschin et al., 2005). The acquisition of embryogenic potential (first step) is largely affected by the genotype, and specifically elicited by stress treatments. Each unique isolated microspore culture step equally contributes to achieve microspore embryogenesis. However, the "real trigger" of the process is based on reprogramming the original route of microspores to sporophytic development.

After microspore cells are triggered to follow the sporophytic route, a multiple step process initiated by several cell divisions takes place leading to the formation of an embryo-like structure. In our study, microspore-derived embryos began to emerge after three to four weeks in the culture medium. Embryos were either floating on the surface of the medium or sinking.

In addition to pretreatment-derived differences, the presence of a gelling agent (Ficoll) in the culture medium also yielded clear differences in the number of embryos and regenerated plants (Table 2). Both 
embryos and regenerated plants were far more abundant when Ficoll was added to the medium. Moreover, the culture could be more easily manipulated because of the higher viscosity of the medium, which reduces injury to the embryos.

The use of Ficoll in the culture medium increases the viscosity and is associated with medium density and osmolality. Eudes \& Amundsen (2005) compared the presence of Ficoll (10\%) in NPB-99 medium for the IMC of triticale, and they observed that the medium supplemented with Ficoll increased the total number of floating embryos, which are considered to be more embryogenic than the sinking ones. This difference was attributed to better gas exchange on the medium surface, which is important for embryo development. The authors also observed that floating embryos were more likely to develop into green plants, and the opposite was true for sinking embryos (produced more albino plants). We observed that the presence of $10 \%$ of Ficoll in the culture medium increased the androgenic response, which resulted in a higher number of embryos and regenerated plants. However, as an exception, the responsive genotype 'Pavon 76 ' produced a higher number of embryos when 2-HNA was applied to the spikes and combined with the induction medium without Ficoll. For this genotype/pretreatment, $13 \%$ of the embryos converted into plants in response to this condition. Taken together, our results indicate that cold $\left(4^{\circ} \mathrm{C}\right)$ and induction medium with Ficoll (10\%) improved embryo formation and plant regeneration.

Regarding embryo formation, three Brazilian genotypes ('MGS 1 Aliança', PF020037, and 'MGS Brilhante') stood out and produced a high number of embryos, in response to cold pretreatment and induction medium containing Ficoll, similarly to 'Pavon 76' (Table 2). Two genotypes ('BR 18 (Terena)' and PF020062) produced a lower number of embryos. 'BR 18 (Terena)' also generated a low number of cells per spike (yield). The low number of embryos could

Table 2. Embryo induction and plant regeneration from isolated microspore culture of six wheat genotypes.

\begin{tabular}{|c|c|c|c|c|c|c|c|c|c|c|c|c|c|c|c|c|}
\hline \multirow[t]{3}{*}{ Genotype } & \multicolumn{8}{|c|}{ Culture medium with Ficoll } & \multicolumn{8}{|c|}{ Culture medium without Ficoll } \\
\hline & \multirow[t]{2}{*}{ Cultured cells } & \multirow[t]{2}{*}{ Embryos } & \multirow[t]{2}{*}{$\operatorname{Total}^{(1)}$} & \multirow[t]{2}{*}{ Albino $^{(2)}$} & \multicolumn{4}{|c|}{ Green } & \multirow{2}{*}{$\begin{array}{l}\text { Cultured } \\
\text { cells }\end{array}$} & \multirow[t]{2}{*}{ Embryos } & \multirow[t]{2}{*}{ Total } & \multirow[t]{2}{*}{ Albino } & \multicolumn{4}{|c|}{ Green } \\
\hline & & & & & $\operatorname{Total}^{(3)}$ & $\mathrm{H}^{(4)}$ & $\mathrm{DH}^{(5)}$ & $\operatorname{Dead}^{(6)}$ & & & & & Total & $\mathrm{H}$ & $\mathrm{DH}$ & Dead \\
\hline & \multicolumn{16}{|c|}{ 2-HNA treatment } \\
\hline 'Pavon 76' & 252,498 & 1,405 & $\begin{array}{l}177 \\
(13)\end{array}$ & $\begin{array}{c}55 \\
(31)\end{array}$ & $\begin{array}{l}122 \\
(69)\end{array}$ & $\begin{array}{c}70 \\
(57)\end{array}$ & $\begin{array}{c}36 \\
(30)\end{array}$ & $\begin{array}{c}16 \\
(13)\end{array}$ & 121,500 & 393 & $\begin{array}{l}181 \\
(46)\end{array}$ & $\begin{array}{l}121 \\
(67)\end{array}$ & $\begin{array}{c}60 \\
(33)\end{array}$ & $\begin{array}{c}30 \\
(50)\end{array}$ & $\begin{array}{c}24 \\
(40)\end{array}$ & $\begin{array}{c}6 \\
(10)\end{array}$ \\
\hline PF020037 & $1,058,637$ & 3 & 0 & 0 & 0 & 0 & 0 & 0 & 751,806 & 186 & $\begin{array}{c}43 \\
(23)\end{array}$ & $\begin{array}{c}23 \\
(53)\end{array}$ & $\begin{array}{c}20 \\
(47)\end{array}$ & $\begin{array}{c}11 \\
(55)\end{array}$ & $\begin{array}{c}7 \\
(35)\end{array}$ & $\begin{array}{c}2 \\
(10)\end{array}$ \\
\hline $\begin{array}{l}\text { 'MGS } 1 \\
\text { Aliança' }\end{array}$ & 265,200 & 46 & $\begin{array}{c}1 \\
(2)\end{array}$ & $\begin{array}{c}1 \\
(100)\end{array}$ & 0 & 0 & 0 & 0 & 46,998 & - & - & - & - & - & - & - \\
\hline $\begin{array}{l}\text { 'MGS } \\
\text { Brilhante' }\end{array}$ & 193,332 & 0 & 0 & 0 & 0 & 0 & 0 & 0 & $*$ & $*$ & $*$ & $*$ & $*$ & $*$ & $*$ & * \\
\hline $\begin{array}{l}\text { 'BR } 18 \\
\text { Terena' }\end{array}$ & 106,665 & 0 & 0 & 0 & 0 & 0 & 0 & 0 & 12,600 & 0 & 0 & 0 & 0 & 0 & 0 & 0 \\
\hline \multirow[t]{2}{*}{ PF020062 } & 489,096 & 19 & 0 & 0 & 0 & 0 & 0 & 0 & 631,098 & 34 & 0 & 0 & 0 & 0 & 0 & 0 \\
\hline & \multicolumn{16}{|c|}{ Cold treatment } \\
\hline 'Pavon 76' & $1,010,328$ & 556 & $\begin{array}{l}205 \\
(37)\end{array}$ & $\begin{array}{l}136 \\
(66)\end{array}$ & $\begin{array}{c}69 \\
(34)\end{array}$ & $\begin{array}{c}19 \\
(28)\end{array}$ & $\begin{array}{c}45 \\
(65)\end{array}$ & $\begin{array}{c}5 \\
(7)\end{array}$ & $1,550,856$ & 1355 & $\begin{array}{l}525 \\
(39)\end{array}$ & $\begin{array}{l}395 \\
(75)\end{array}$ & $\begin{array}{l}130 \\
(22)\end{array}$ & $\begin{array}{c}39 \\
(30)\end{array}$ & $\begin{array}{c}85 \\
(65)\end{array}$ & $\begin{array}{c}6 \\
(5)\end{array}$ \\
\hline PF020037 & $1,298,313$ & 143 & $\begin{array}{c}8 \\
(6)\end{array}$ & $\begin{array}{c}8 \\
(100)\end{array}$ & 0 & 0 & 0 & 0 & $1,739,643$ & 1062 & $\begin{array}{l}199 \\
(19)\end{array}$ & $\begin{array}{l}115 \\
(58)\end{array}$ & $\begin{array}{c}84 \\
(42)\end{array}$ & $\begin{array}{c}34 \\
(41)\end{array}$ & $\begin{array}{c}44 \\
(52)\end{array}$ & $\begin{array}{c}6 \\
(7)\end{array}$ \\
\hline $\begin{array}{l}\text { 'MGS } 1 \\
\text { Aliança' }\end{array}$ & $1,104,867$ & 532 & $\begin{array}{c}88 \\
(16)\end{array}$ & $\begin{array}{c}77 \\
(87,5)\end{array}$ & $\begin{array}{c}11 \\
(12,5)\end{array}$ & $\begin{array}{c}1 \\
(9)\end{array}$ & $\begin{array}{c}10 \\
(82)\end{array}$ & $\begin{array}{c}1 \\
(9)\end{array}$ & $1,104,867$ & 1107 & $\begin{array}{l}196 \\
(18)\end{array}$ & $\begin{array}{c}179 \\
(910)\end{array}$ & $\begin{array}{l}17 \\
(9)\end{array}$ & $\begin{array}{c}9 \\
(53)\end{array}$ & $\begin{array}{c}7 \\
(41)\end{array}$ & $\begin{array}{c}1 \\
(6)\end{array}$ \\
\hline $\begin{array}{l}\text { 'MGS } \\
\text { Brilhante' }\end{array}$ & $1,503,858$ & 471 & $\begin{array}{l}11 \\
(2)\end{array}$ & $\begin{array}{c}6 \\
(55)\end{array}$ & $\begin{array}{c}5 \\
(45)\end{array}$ & $\begin{array}{c}1 \\
(20)\end{array}$ & $\begin{array}{c}4 \\
(80)\end{array}$ & 0 & $1,718,457$ & 1022 & $\begin{array}{l}32 \\
(3)\end{array}$ & $\begin{array}{c}13 \\
(41)\end{array}$ & $\begin{array}{c}19 \\
(59)\end{array}$ & $\begin{array}{c}6 \\
(32)\end{array}$ & $\begin{array}{c}12 \\
(63)\end{array}$ & $\begin{array}{c}1 \\
(5)\end{array}$ \\
\hline $\begin{array}{l}\text { 'BR } 18 \\
\text { Terena' }\end{array}$ & 975,121 & 0 & 0 & 0 & 0 & 0 & 0 & 0 & 775,122 & 122 & $\begin{array}{c}41 \\
(34)\end{array}$ & $\begin{array}{c}27 \\
(66)\end{array}$ & $\begin{array}{c}14 \\
(34)\end{array}$ & $\begin{array}{c}9 \\
(64)\end{array}$ & $\begin{array}{c}5 \\
(36)\end{array}$ & 0 \\
\hline PF020062 & $1,282,956$ & 0 & 0 & 0 & 0 & 0 & 0 & 0 & $1,268,136$ & 7 & 0 & 0 & 0 & 0 & 0 & 0 \\
\hline
\end{tabular}

${ }^{(1)}$ Total regenerated plants (\% embryos). ${ }^{(2)} \mathrm{Albino}$ plants (\% total regenerated plants). ${ }^{(3)}$ Total green plants $\left(\%\right.$ total regenerated plants). ${ }^{\left({ }^{(}\right)} \mathrm{Haploid}$ plants $(\%$ green plants). ${ }^{(5)}$ Doubled haploid (\% spontaneous DH plants/green plants). ${ }^{(6)}$ Total dead plants (\% green plants). *Not enough cells. 
be associated with the low yield of cells. However, PF020062 exhibited high yields and produced only seven embryos.

As expected, 'Pavon 76' produced the highest total percentage of regenerated plants $(46 \%$ of embryos converted into plants). Two Brazilian genotypes were moderately responsive: PF020037 (19\%) and 'MGS 1 Aliança' (18\%). 'MGS Brilhante' produced a substantial amount of embryos $(1,022)$, but only $3 \%$ of them regenerated into plants. Conversely, 'BR 18 (Terena)' produced very few embryos (122), but 34\% converted into plants. PF020062 was highly recalcitrant, producing the lowest number of embryos, and no plants.

Albino plants were observed in most genotypes (except for PF020062). 'MGS 1 Aliança' and 'Pavon 76' produced the highest percentages of albino plants (91 and $75 \%$, respectively, Table 2). In addition to genotypic limitations, the high frequency of albino plants has largely affected the production of $\mathrm{DH}$ plants in cereals (Jacquard et al., 2009; Kumari at al., 2009). In many cases, albinism can be observed in up to $100 \%$ of regenerated plants (Labbani et al., 2005). Diverse factors could influence the rate of albinism: the genotype and physiological conditions of donor plants, pretreatment temperatures, meiotic abnormalities, hormonal imbalances, mutations, and incompatibility between plastid and nuclear genomes (Kumari et al., 2009). Albino plants could also be a result of the maternal inheritance of plastids, a hypothesis first proposed by Vaughn et al. (1980). However, other studies have shown that not all albino plants carry plastid DNA deletions (Torp \& Andersen, 2009).

Although deletions and the reorganization of plastid genomes were observed in wheat, barley (Day \& Ellis, 1984, 1985) and rice (Harada et al., 1991, 1992), albinism is also related to altered transcript patterns and translation levels (Ankele et al., 2005).

A lack of chlorophyll in albino plants is usually governed by one or two recessive genes, although more genes control this genetic trait in some species, including additive and nonadditive genes (Kumari et al., 2009). Because it is a recessive trait, albinism is difficult to eradicate from a population; the allele will persist at a low frequency in heterozygous plants. However, some approaches could minimize the frequency of albino phenotypes. The addition of copper sulfate to the pretreatment and culture medium of barley anthers increased the anther response by $15 \%$, and the number of green plants by $400 \%$ (Wojnarowiez et al., 2002). Jacquard et al. (2009) showed that this modification increased the number of DH plants and reduced the number of albino plants in barley anther culture, including the presence of green plants in a genotype that regenerated only albino plants.

The total number of green plants $(\mathrm{H}, \mathrm{DH}$, and dead plants) and the percentage of green plants (total) were recorded for all genotypes, varying from 9 to $59 \%$ among evaluated genotypes. Spontaneous chromosome doubling was recorded by checking the seed set. The overall efficiency of chromosome doubling ranged from $36 \%$ in 'BR 18 Terena' to $63 \%$ in 'MGS Brilhante'.

Three types of regenerated plants were observed: plants containing sterile spikes only, plants having fertile spikes only, and plants presenting fertile and sterile spikes (Figure 1 A). Additionally, four different types of spikes were found: fertile, partially fertile, sterile, and atypical (always sterile and with the same phenotype) (Figure 1 B). Phenotype alterations of spikes did not differ between genotypes.

Genome duplication is a very important step to recover the fertility of the $\mathrm{H}$ plant. The spontaneous doubling of chromosomes in anther or microspore culture is highly desirable because it avoids artificial chromosome doubling, which is time-consuming, costly, and inefficient. Induced chromosome doubling by chemical agents, such as colchicine, results in high mortality rates, which decreases the process efficiency (Castillo et al., 2009). Four different mechanisms were identified as responsible for spontaneous chromosome doubling: endoreduplication, a type of cell cycle in which nuclear chromosomal DNA replication occurs without cell division; nuclear fusion; endomitosis; and c-mitosis (Testillano et al., 2004). However, the precise mechanism is not well understood, and the factors leading to these processes remain unknown, but are highly susceptible to the in vitro conditions (Testillano et al., 2004). Differences between genotypes can also influence the doubling of the chromosome set (Indrianto et al., 1999). Castillo et al. (2009) reported doubling rates of chromosomes varying from 25 to $75 \%$ for bread wheat.

Our results corroborate the hypothesis that spontaneous genome duplication is genotypedependent, ranging from 35\%, for 'BR 18 (Terena)', to 
$63 \%$ for 'MGS Brilhante'; besides $65 \%$ for the responsive genotype 'Pavon 76'. Types of pretreatments and the presence of Ficoll in the culture medium also affected chromosome duplication exhibiting high variability for this trait. Indrianto et al. (1999) reported similar results for spontaneous chromosome doubling. The authors observed that cold pretreatment resulted in a higher number of spontaneous diploids than heat or starvation. Kasha et al. (2001) also observed that cold or cold plus mannitol had the same effect, that is: higher spontaneous doubling rates compared with other pretreatments. In general, chromosome doubling will mostly occur at the beginning of cell division. The low frequency of chimeric plants observed in our study suggests that chromosome doubling took place very early during in vitro cultivation, most likely at the time of induction,

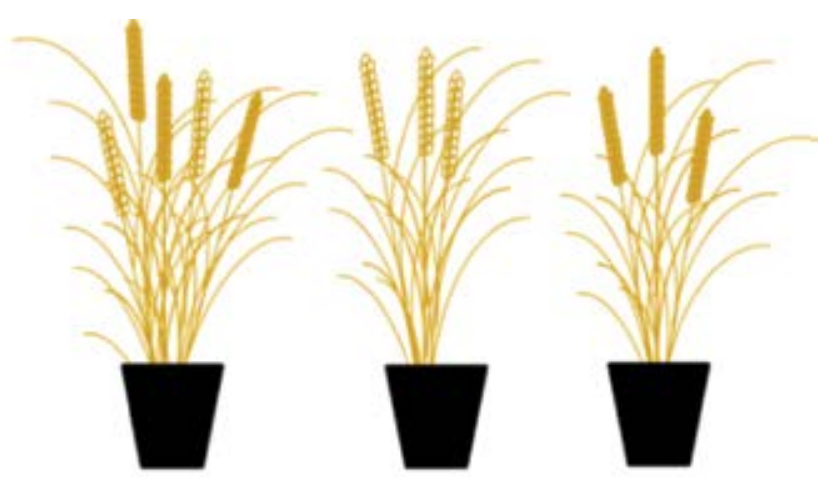

A $\mathrm{DH}+\mathrm{H}$
$\mathrm{H}$
$\mathrm{DH}$

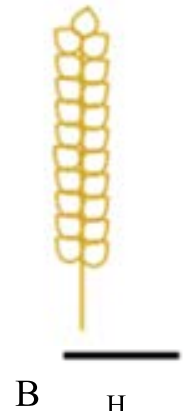

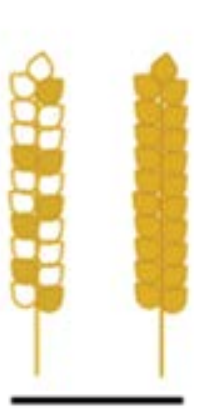

DH

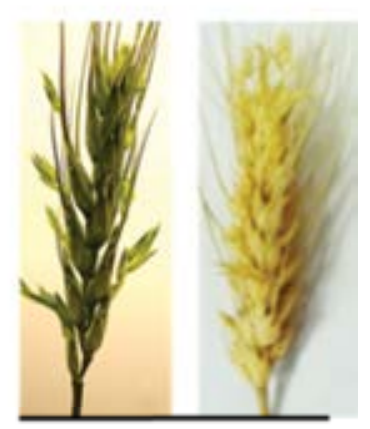

Atypical
Figure 1. Types of plants and spikes obtained from microspore culture. A) Three types of regenerated plants: $\mathrm{DH}+\mathrm{H}$, containing fertile and sterile spikes; $\mathrm{H}$, containing only sterile spikes; and DH, containing only fertile spikes. B) Four types of spikes: H, completely sterile spike; DH, partially fertile or completely fertile spike; and atypical, spikes with different phenotypes, always sterile. as suggested by Kasha et al. (2001). However, even at low frequencies, the presence of mixoploid plants indicates that chromosome doubling did not occur in all tissue cells. Lantos et al. (2006) also reported chimeric wheat plants with different chromosome numbers that exhibited fertile, partial fertile, and sterile spikes obtained from IMC. According to the authors, spikes abnormalities were likely due to the intrinsic in vitro culture process, and they are not caused by artificial chromosome duplication.

\section{Conclusions}

1. Cold shock triggers androgenesis more effectively than chemical treatment with 2-HNA.

2. Induction culture medium containing $10 \%$ Ficoll produces more embryos and green plants than induction medium without Ficoll.

3. Albinism is the restraining factor for all tested genotypes, since its incidence ranged from $41 \%$ for 'MGS Brilhante') to $91 \%$ for 'MGS 1 Aliança'.

4. The DH protocol via IMC should be substantially improved to be cost effective and efficient.

\section{Acknowledgments}

To Coordenação de Aperfeiçoamento de Pessoal de Nível Superior (Capes), for the scholarship granted and to Embrapa Trigo, for financial support.

\section{References}

ABDOLLAHI, M.R.; MOIENI, A.; MOUSAVI, A.; SALMANIAN, A.H.; JALALI JAVARAN, M.; MAJDI, M. Effect of integrated bombardment and Agrobacterium transformation system on transient GUS expression in hypocotyls of rapeseed (Brassica napus L. cv. $\mathrm{PF}_{704}$ ) microspore-derived embryos. Pakistan Journal of Biological Science, v.10, p.3141-3145, 2007. DOI: 10.3923/pjbs.2007.3141.3145.

ANKELE, E.; HEBERLE-BORS, E.; PFOSSER, M.F.; HOFINGER, B.J. Searching for mechanisms leading to albino plant formation in cereals. Acta Physiologiae Plantarum, v.27, p.651-665, 2005. DOI: 10.1007/s11738-005-0069-4.

ASIF, M. Progress and opportunities of doubled haploid production. Cham: Springer, 2013. 85p. DOI: 10.1007/978-3-31900732-8.

BLAKESLEE, A.F.; BELLING, J.; FARNHAM, M.E.; BERGNER, A.D. A haploid mutant in the jimson weed, "Datura stramonium". Science, v.55, p.646-647, 1922. DOI: 10.1126/ science.55.1433.646. 
CASTILlO, A.M.; CISTUÉ, L.; VALLÉS, M.P.; SORIANO, M. Chromosome doubling in monocots. In: TOURAEV, A.; FORSTER, B.P.; JAIN, S.M. (Ed.). Advances in haploid production in higher plants. [S.1.]: Springer, 2009. p.329-338. DOI: 10.1007/978-1-4020-8854-4_27.

DAY, A.; ELLIS, T.H.N. Chloroplast DNA deletions associated with wheat plants regenerated from pollen: possible basis for maternal inheritance of chloroplasts. Cell, v.39, p.359-368, 1984. DOI: 10.1016/0092-8674(84)90014-X.

DAY, A.; ELLIS, T.H.N. Deleted forms of plastid DNA in albino plants from cereal anther culture. Current Genetics, v.9, p.671678, 1985. DOI: 10.1007/BF00449820.

EUDES, F.; ACHARYA, S.; LAROCHE, A.; SELINGER, L.B.; CHENG, K.-J. A novel method to induce direct somatic embryogenesis, secondary embryogenesis and regeneration of fertile green cereal plants. Plant Cell, Tissue and Organ Culture, v.73, p.147-157, 2003. DOI: 10.1023/A:1022800512708.

EUDES, F.; AMUNDSEN, E. Isolated microspore culture of Canadian 6x triticale cultivars. Plant Cell, Tissue and Organ Culture, v.82, p.233-241, 2005. DOI: 10.1007/s11240-005-0867-9.

FERRIE, A.M.R; CASWELL, K.L. Isolated microspore culture techniques and recent progress for haploid and doubled haploid plant production. Plant Cell, Tissue and Organ Culture, v.104, p.301-309, 2011. DOI: 10.1007/s11240-010-9800-y.

GERMANÀ, M.A. Anther culture for haploid and doubled haploid production. Plant Cell, Tissue and Organ Culture, v.104, p.283300, 2011. DOI: 10.1007/s11240-010-9852-z.

GUHA, S.; MAHESHWARI, S.C. In vitro production of embryos from anthers of Datura. Nature, v.204, p.497, 1964. DOI: $10.1038 / 204497 \mathrm{a} 0$.

HARADA, T.; ISHIKAWA, R.; NIIZEKI, M.; SAITO, K. Pollenderived rice calli that have large deletions in plastid DNA do not require protein synthesis in plastids for growth. Molecular and General Genetics, v.233, p.145-150, 1992. DOI: 10.1007/ BF00587572.

HARADA, T.; SATO, T.; ASAKA, D.; MATSUKAWA, I. Largescale deletions of rice plastid DNA in anther culture. Theoretical and Applied Genetics, v.81, p.157-161, 1991. DOI: 10.1007/ BF00215717.

INDRIANTO, A.; HEBERLE-BORS, E.; TOURAEV, A. Assessment of various stresses and carbohydrates for their effect on the induction of embryogenesis in isolated wheat microspores. Plant Science, v.143, p.71-79, 1999. DOI: 10.1016/S01689452(99)00022-9.

JACQUARD, C.; NOLIN, F.; HÉCART, C.; GRAUDA, D.; RASHAL, I.; DHONDT-CORDELIER, S.; SANGWAN, R.S.; DEVAUX, P.; MAZEYRAT-GOURBEYRE, F.; CLÉMENT, C. Microspore embryogenesis and programmed cell death in barley: effects of copper on albinism in recalcitrant cultivars. Plant Cell Reports, v.28, p.1329-1339, 2009. DOI: 10.1007/s00299-0090733-z.

KASHA, K.J.; HU, T.C.; ORO, R.; SIMION, E.; SHIM, Y.S. Nuclear fusion leads to chromosome doubling during mannitol pretreatment of barley (Hordeum vulgare L.) microspores.
Journal of Experimental Botany, v.52, p.1227-1238, 2001. DOI: 10.1093/jexbot/52.359.1227.

KONZAK, C.F.; POLLE, E.A.; LIU, W.; ZHENG, Y. Methods for generating doubled-haploid plants. Published international patent application. PCT/US99/19498, 16 mar. 2000.

KUMARI, M.; CLARKE, H.J.; SMALL, I.; SIDDIQUE, K.H.M. Albinism in plants: a major bottleneck in wide hybridization, androgenesis and doubled haploid culture. Critical Reviews in Plant Science, v.28, p.393-409, 2009. DOI: 10.1080/07352680903133252.

LABBANI, Z.; RICHARD, N.; DE BUYSER, J.; PICARD, E. Chlorophyllian durum wheat plants obtained by isolated microspores culture: importance of the pre-treatments. Comptes Rendus Biologies, v.328, p.713-723, 2005. DOI: 10.1016/j. crvi.2005.05.009.

LANTOS, C.; PÁRICSI, S.; ZOFAJOVA, A.; WEYEN, J.; PAUK, J. Isolated microspore culture of wheat (Triticum aestivum L.) with Hungarian cultivars. Acta Biologica Szegediensis, v.50, p.31-35, 2006.

LIU, W.; ZHENG, M.Y.; POLLE, E.A.; KONZAK, C.F. Highly efficient doubled-haploid production in wheat (Triticum aestivum L.) via induced microspore embryogenesis. Crop Science, v.42, p.686-692, 2002. DOI: 10.2135/cropsci2002.0686.

MARASCHIN, S.F.; DE PRIESTER, W.; SPAINK, H.P.; WANG, M. Androgenic switch: an example of plant embryogenesis from the male gametophyte perspective. Journal of Experimental Botany, v.56, p.1711-1726, 2005. DOI: 10.1093/jxb/eri190.

SEYMOUR, D.K.; FILIAULT, D.L.; HENRY, I.M.; MONSONMILLER, J.; RAVI, M.; PANG, A.; COMAI, L.; CHAN, S.W.L.; MALOOF, J.N. Rapid creation of Arabidopsis doubled haploid lines for quantitative trait locus mapping. Proceedings of the National Academy of Sciences of the United States of America, v.109, p.4227-4232, 2012. DOI: 10.1073/pnas.1117277109.

SHARIATPANAHI, M.E.; BELOGRADOVA, K.; HESSAMVAZIRI, L.; HEBERLE-BORS, E.; TOURAEV, A. Efficient embryogenesis and regeneration in freshly isolated and cultured wheat (Triticum aestivum L.) microspores without stress pretreatment. Plant Cell Reports, v.25, p.1294-1299, 2006. DOI: 10.1007/s00299-006-0205-7.

SHIRDELMOGHANLOO, H.; MOIENI, A.; MOUSAVI, A. Effects of embryo induction media and pretreatments in isolated microspore culture of hexaploid wheat (Triticum aestivum L. cv. Falat). African Journal of Biotechnology, v.8, p.6134-6140, 2009. DOI: 10.5897/AJB09.350.

TESTILlANO, P.; GEORGIEV, S.; MOGENSEN, H.L.; CORONADO, M.J.; DUMAS, C.; RISUENO, M.C.; MATTHYSROCHON, E. Spontaneous chromosome doubling results from nuclear fusion during in vitro maize induced microspore embryogenesis. Chromosoma, v.112, p.342-349, 2004. DOI: 10.1007/s00412-004-0279-3.

TORP, A.M.; ANDERSEN, S.B. Albinism in microspore culture. In: TOURAEV, A.; FORSTER, B.P.; JAIN, S.M. (Ed.). Advances in haploid production in higher plants. [S.1.]: Springer, 2009. p.155-160. DOI: 10.1007/978-1-4020-8854-4_12.

VAUGHN, K.C.; DEBONTE, L.R.; WILSON, K.G.; SCHAFFER, G.W. Organelle alteration as a mechanism for maternal 
inheritance. Science, v.208, p.196-198, 1980. DOI: 10.1126/ science.208.4440.196.

WOJNAROWIEZ, G.; JACQUARD, C.; DEVAUX, P.; SANGWAN, R.S.; CLÉMENT, C. Influence of copper sulphate on anther culture in barley (Hordeum vulgare L.). Plant Science, v.162, p.843-847, 2002. DOI: 10.1016/S0168-9452(02)00036-5.
ZORINIANTS, S.; TASHPULATOV, A.S.; HEBERLE-BORS, E.; TOURAEV, E. The role of stress in the induction of haploid microspore embryogenesis. In: DON PALMER, C.E.; KELLER, W.A.; KASHA, K.J. (Ed). Haploids in crop improvement II. Berlin: Springer, 2005. p.35-52. (Biotechnology in agriculture and forestry, v.56). DOI: 10.1007/3-540-26889-8_3.

Received on May 29, 2015 and accepted on July 8, 2016 